\title{
Differential Responses of Organic Manure and Biofertilizer on Morphophenological Traits and Yield Attributes of Cherry Tomato (Solanum lycopersicum var cerasiformae) Genotypes
}

\author{
Ankita Sharma*, D. P. Sharma, S. K. Pandey and T. R. Sharma \\ Department of Horticulture, College of Agriculture, J.N.K.V.V., \\ Jabalpur - 482004, (M.P.), India \\ *Corresponding author
}

Ke y w o r d s
Cherry tomato,
Genotypes,
Vermicompost,
Azotobacter,
Morphological traits
Article Info
Accepted:
26 September 2020
Available Online:
10 October 2020

\section{A B S T R A C T}

The present investigation was conducted at Horticulture complex, Department of Horticulture, Jawaharlal Nehru Krishi Vishwa Vidyalaya, Jabalpur (M.P.) during the Rabi season in 2018-19 under open field condition. The experiment was laid out in complete randomized block design asymmetrical (factorial) with five levels of genotypes and three levels of vermicompost doses with three replications. The results revealed that among the Genotypes, G4 2018/TOC VAR-4 recorded significantly higher values for morphological and phenological traits such as plant height $(66.74$ and $123.96 \mathrm{~cm})$ at 60 and 120 DAT, minimum days taken to first flower (29.84), minimum days to first picking (81.3 days), with average fruit weight $45.50 \mathrm{~g}$, mean number of fruits per plants (144.3), yield per plant $(0.82 \mathrm{~kg})$ and fruit yield per ha $\left(272.52 \mathrm{qha}^{-1}\right)$. Maximum number of branches per plant at final harvest (15.32), minimum days to first flower (29.35 days), early harvesting (81.3 days), average fruit weight $(41.18 \mathrm{~g})$, fruit yield per plant $(0.87 \mathrm{~kg})$ and yield per hectare $\left(289.60 \mathrm{qha}^{-1}\right)$ were best results obtained under the application of vermicompost 5tha ${ }^{-1}$ and Azotobacter $4 \mathrm{kgha}^{-1}(\mathrm{~B} 3)$. T9 having Vermicompost $\left(5 \mathrm{tha}^{-1}\right.$ ) and Azotobacter $\left(4 \mathrm{Kgha}^{-1}\right.$ ) in genotype $2018 /$ TOC VAR-4 resulted in significantly maximum plant height $39.87,74.91,100.14$ and $129.17 \mathrm{~cm}$ at 30,60, 90, and 120 DAT respectively, number of 16.16 branches $\mathrm{pl}^{-1}$, minimum days (28.69) for days taken to first flowering, final harvesting at 124 days, maximum fruit weight $(49.37 \mathrm{~g})$, fruit diameter $(3.07 \mathrm{~cm})$, number of 168.65 fruits per plant, yield $0.92 \mathrm{Kg} \mathrm{pl}^{-1}$ and fruit yield per hectare(307.78qha ${ }^{-1}$ ).

\section{Introduction}

Cherry tomato (Solanum lycopersicum var. cerasiformae) is botanically a small sized variety of the cultivated form of Tomato. (Lenucci et al., 2006). Cherry tomato is a member of the family Solanaceae and is thought to have originated from Peru and
North Chile (Andrew, 1994). Jenkins, 1948 stated that the cultivated tomato lines were actually derived from Lycopersicum esculentum var. cerasiformae through domestication. The cerasiforme types can be singled out from the cultivated types by the presence of a slightly excreted stigma in the flowers. Prema et al., (2011) revealed that the 
variety of cherry tomato can be considered similar but not identical to wild relatives of domestic tomato. These small table purpose tomatoes are broadly cultivated in Central America and are scattered to regions of California, Korea, Germany, Mexico and Florida. The fruits are less than half the size of cultivated forms weighing 10 to $30 \mathrm{~g}$ and the shape varies from spherical to oblong. These are commonly referred to as 'Salad tomato' as are consumed as salad fruit rather than as a vegetable. These have a delicious sweeter taste, with a pleasing appearance, intense flavour and colour with significant nutritional benefits. The edible fruits are perfect for making ornamental dishes and processed products such as sauce, puree, ketchup, paste, powder, soup, curries, rasam and in sandwich. (Anonymous, 2009).

Cherry tomato is a self-pollinated crop having a growth habit of determinate, semideterminate and indeterminate. Due to the non-availability of high yielding adaptable variety, the area and productivity of cherry tomato in India is very low in contrast to other countries. It is a sensitive vegetable that gets affected due to a slight variation in weather parameters leading to significant changes in the growth physiology of the crop causing considerable yield loss. These can be easily adapted by small farmers as are rustic, resistant to disease, can tolerate high relative humidity and easily marketable possessing 5 to 15 fruits per cluster.

The objective of the paper is to evaluate the effect of vermicompost and biofertilizer Azotobacter on the growth and productivity of different genotypes of Cherry tomato.

\section{Materials and Methods}

The present investigation was carried out at Horticulture complex, Department of Horticulture, Jawaharlal Nehru Krishi Vishwa
Vidyalaya, Jabalpur (M.P.) during the year Rabi season in 2018-19 with a view to ascertain a better suited genotype with respect to different organic fertilizer doses for Cherry tomato under agro-climatic and soil conditions Madhya Pradesh. This study was conducted to examine the morphological characteristics and yield performance of Cherry tomato under open field conditions using vermicompost and Azotobacter.

The experiment was laid out in Factorial Randomized Block Design with three replications and each replication consisted of fifteen treatments. The experimental material for the present investigation comprised of fifteen treatment combination of five genotypes viz. 2018/TOC VAR-1, 2018/TOC VAR-2, 2018/TOC VAR-4, 2018/TOC VAR5, 2018/TOC VAR-6 which are Genotypes G1, G2, G4, G5 and G6 respectively and three doses of vermicompost and Azotobacter viz. Control (RDF), Vermicompost $\left(2.5\right.$ tha $\left.^{-1}\right)+$ Azotobacter $\left(4 \mathrm{kgha}^{-1}\right)$ and Vermicompost $\left(5\right.$ tha $\left.^{-1}\right)+$ Azotobacter $\left(4 \mathrm{kgha}^{-1}\right)$.

Seeds of Cherry Tomato were obtained from IIVR, Varanasi. The nursery beds were dug and prepared thoroughly. After sowing seeds were covered with a thin layer of sieved FYM. Sprinkling of water was done immediately to make the beds well moisturized till the germination. Seeds of different genotypes were treated with Thiram @ $2 \mathrm{gkg}^{-1}$ of seeds before sowing and were sown in November 2018 in separate bed uniformly at a depth of $2-3 \mathrm{~cm}$. Before the execution of experiment, the field was well ploughed by tractor followed by planking and harrowed in order to bring the soil in a wellpulverized condition. Plots were made according to the layout plan. To enrich the soil, well-rotten FYM @ 25 tha $^{-1}$ was applied. Fifteen days prior to actual date of transplanting of seedling; weeds, stones, pebbles etc. were removed to make the field 
clean and brought to a fine tilth. Seedlings were uprooted from the nursery bed and transplanted in the plots at a spacing of $60 \mathrm{~cm}$ row to row and $50 \mathrm{~cm}$ plant to plant. Light irrigation was given before uprooting seedlings from the nursery beds so that minimum damage may occur to the roots of the seedling. A week after transplanting gap filling was done. Each plot had 4 rows accommodating 16 plants. The seedlings were raised with all precautions and healthy seedlings were transplanted. The experimental plots were kept weed free. Well rotted FYM was applied @ 20tha ${ }^{-1}$ before second harrowing while preparing the field. Nitrogen, Phosphorus and Potash were applied @ 150, 80, and $100 \mathrm{kgha}^{-1}$ in the form of Urea, Diammonium phosphate (DAP) and Murate of potash (MOP), respectively. Half of the nitrogen and full amount of the phosphorus and potash were given as basal dose at the time of transplanting, while the remaining half quantity of nitrogen was applied in two equal splits at 25 and 45 days after transplanting as top dressing. Biofertilizer Azotobacter (4 kg ha ${ }^{-1}$ each) was applied to the soil after mixing with vermicompost 2.5 tha ${ }^{-1}$ and 5 tha $^{-1}$ as per the treatments for uniform distribution one week after transplanting. Neem soaked kernel extract (NSKE $5 \%$ ) for leaf eating caterpillars and Dimethoate $0.03 \%$ for fruit borer alternate to keep the crop free from pest during the crop growth period.

The data recorded on various parameters were subdivided into different categories during the period of experimentation. The data were recorded as per the standard procedure. The morphophysiological parameters were recorded at various stages of crop growth and harvest. The data was recorded for the morphological parameters on Plant height $(\mathrm{cm})$ at 30,60,90 and 120 DAT, Number of branches per plant (at final harvest) and Number of Leaves per plant (at final harvest); Phenological parameters on Days taken to first flowering, Days taken to $50 \%$ flowering and Number of flower per cluster and Yield attributes such as Days to first fruit picking, Days to last fruit picking, Fruiting span, Number of fruits per plant, Average Fruit weight $(\mathrm{g})$, Fruit diameter $(\mathrm{cm})$, Fruit yield per plant $(\mathrm{kg})$ and Fruit yield per ha (q).

\section{Results and Discussion}

The data obtained from the periodical field observations pertaining to morphological, physiological and phenological growth and yield-attributing characters of Cherry tomato were tabulated and then statistically computed.

\section{Morphological parameters}

The result revealed that Genotypes, Vermicompost doses and their interactions significantly influenced growth parameters. Among Genotypes, G4 2018/TOC VAR-4 exhibited enhancement in plant growth parameters (viz., plant height, branches plant ${ }^{-1}$ and the Number of leaves) when compared to the control. A General increase in the plant height from $34.73 \mathrm{~cm}$ to 123.96 was observed with the advancement of growth stage under G4, G5 and G6 between 30-120 DAT whereas the minimum height was noted under genotype 2018/TOC VAR-1 is represented through Graph 1. The maximum number of 13.9 branches $\mathrm{pl}^{-1}$ at the final harvest was noted under genotype 2018/TOC VAR-6. Application of different levels of biofertilizer and vermicompost influences the number of compound leaves in cherry tomato. The maximum number 92.28 leaves per plant were noted in Genotype 2018/TOC VAR-6 and the minimum value was recorded in G1 2018/TOC VAR-1 (84.16 leaves) at final harvest under open field condition. Due to its long harvest duration, indeterminate growth 
habit is preferred. Profused branches results in more leaf production, which enhances the efficiency of photosynthetic activity which leads to a greater growth and high yield. The results so obtained was in agreement with the findings of the researchers Nitzsche et al., (2003), Kumar et al.,(2014) and Renuka et al., (2014) during the evaluation of cherry tomato.

Among the vermicompost levels, the result indicated that the plant height 37.9-123.42 cm was significantly maximum in the treatment comprising of Vermicompost $\left(5 \mathrm{tha}^{-1}\right)$ along with Azotobacter $\left(4 \mathrm{kgha}^{-1}\right)(\mathrm{B} 3)$, while the minimum plant height $(30.94-113.16 \mathrm{~cm})$ was recorded under $100 \%$ RDF (B1) between 30 to 120 DAT. Chumyani et al., (2012) reported that the productivity and yield can be increased due to the application of different levels of fertilizers, organic manures and biofertilizers either alone or in combination. Maximum number of 91.94 leaves was recorded under B3 having vermicompost 5 tha $^{-1}$ and Azotobacter $4 \mathrm{kgha}^{-1}$ while minimum number of 84.84 leaves was recorded under B1 (control). The maximum number of 15.3 branches $\mathrm{pl}^{-1}$ was observed under B3 and minimum 11.5 branches $\mathrm{pl}^{-1}$ was recorded under Control (B1) as illustrated in Table 1. This may be attributed to have increased due to better nutrient availability due to organic manure and biofertilizer, better nutrient uptake and enhanced photosynthetic activity. These are in agreement with the findings of Chatterjee et al., (2014) in Tomato grown using organic and inorganic manures and different compositions of biofertilizers.

The plant height of Cherry tomato gave significant results to different treatment combinations. G4B3 (2018/TOC VAR-6 under 5 tha $^{-1}$ Vermicompost + Azotobacter $)$ resulted maximum plant height $(129.17 \mathrm{~cm})$ and minimum plant height $(104.96 \mathrm{~cm})$ was obtained in case of treatment combination
G1B1 (2018/TOC VAR-1 + 100\% RDF). Najar and Khan (2013) found the highest shoot length $(76 \mathrm{~cm})$ with the application of vermicompost @6tha ${ }^{-1}$. Abduli et al., (2013) observed the highest plant height with vermicompost: soil (1:1) ratio. Rodge and Yadlod (2009) and Senapati et al., (2007) found significant plant height from the treatment combination (50\% recommended dose of fertilizer $+50 \%$ vermicompost).

G4B3 (T9) 2018/TOC VAR-4 Vermicompost $\left(5\right.$ tha $\left.^{-1}\right)$ and Azotobacter $\left(4 \mathrm{Kgha}^{-1}\right)$ showed a significant maximum number 16.16 of branches $\mathrm{pl}^{-1}$ while minimum 10.6 branches were reported in $\mathrm{T} 1$. The maximum number of 96.37 leaves $\mathrm{pl}^{-1}$ was recorded under G6 grown with vermicompost 5 tha $^{-1}$ and Azotobacter $4 \mathrm{kgha}^{-1}$ which was statistically at par with G4 at same level of organic manure. The minimum number of 81.80 leaves $\mathrm{pl}^{-1}$ was recorded at harvest under $\mathrm{T} 1$ which is Genotype 2018/TOC VAR-4 control (RDF).

These findings were in conformation with the findings of Gajbhiya et al., (2003), Kumar et al., (2011) and Patil et al., (2010) in tomato crop.

\section{Phenological parameters}

Significant influence was observed among treatments Genotypes, vermicompost levels and their interactions for days to first flowering, 50 per cent flowering and flowers per cluster. The mean performance of the phenological parameters is compiled in Table 2.

Desirable genotype is the one that follows early flowering. Genotype 2018/TOC VAR-4 took Minimum days to first flower (29.85 days) and 50 per cent flowering (38.36 days) and produced a maximum number of 5.85 flowers per cluster and showed superiority over the rest of the treatments. Such earliness 
in cherry tomato was owing to its higher capacity to furnish the available assimilates to the apex during the sensitive phase before initiation Prema et al., (2011). The results are in concurrence with the findings of Peires (2002), Anand (2007) and Alam et al., (2014). Maximum days to first flower (32.35), and 50 per cent flowering (41.73 days) were noted in
Genotype 2018/TOC VAR-2. But, minimum number of flowers per cluster was noted in G1 2018/TOCVAR-1. Development of genotypes with more flower number cluster $^{-1}$ helps to increase the yield through more fruit number plant ${ }^{-1}$. Renuka et al., (2014) drew similar conclusions while evaluating Cherry tomato lines.

Table.1 Mean performance of Plant height (cm), Number of branches and number of leaves

\begin{tabular}{|c|c|c|c|}
\hline \multirow[t]{2}{*}{ Treatments } & $\begin{array}{c}\text { Plant height (cm) } \\
\text { at }\end{array}$ & $\begin{array}{c}\text { Number of } \\
\text { branches }\end{array}$ & Number of leaves \\
\hline & 120 DAT & At final harvest & At final harvest \\
\hline \multicolumn{4}{|l|}{ Different Genotypes } \\
\hline G1 2018/TOC VAR-1 & 110.21 & 12.95 & 84.15 \\
\hline G2 2018/TOC VAR-2 & 115.05 & 13.48 & 86.21 \\
\hline G4 2018/TOC VAR-4 & 123.96 & 13.77 & 89.27 \\
\hline G5 2018/TOC VAR-5 & 118.56 & 13.72 & 89.96 \\
\hline G6 2018/TOC VAR-6 & 123.51 & 13.94 & 92.27 \\
\hline S.Em \pm & 0.44 & 0.21 & 0.52 \\
\hline C.D.5\% level & 1.29 & 0.58 & 1.52 \\
\hline \multicolumn{4}{|l|}{ Vermicompost doses } \\
\hline B1 Control & 113.16 & 11.54 & 84.84 \\
\hline B2 Vermicompost 2.5tha ${ }^{-1}$ & 118.18 & 13.85 & 88.35 \\
\hline B3 Vermicompost 5 tha $^{-1}$ & 123.42 & 15.33 & 91.94 \\
\hline S.Em \pm & 0.31 & 0.15 & 0.37 \\
\hline C.D.5\% level & 0.92 & 0.42 & 1.07 \\
\hline \multicolumn{4}{|l|}{ Interactions } \\
\hline T1 G1B1 & 104.98 & 11.21 & 81.80 \\
\hline T2 G1B2 & 109.63 & 13.01 & 83.66 \\
\hline T3 G1B3 & 116.02 & 14.65 & 87.00 \\
\hline T4 G2B1 & 108.75 & 10.67 & 82.50 \\
\hline T5 G2B2 & 114.81 & 14.29 & 86.63 \\
\hline T6 G2B3 & 121.59 & 15.48 & 89.50 \\
\hline T7 G4B1 & 118.42 & 11.48 & 85.33 \\
\hline T8 G4B2 & 124.3 & 13.68 & 88.33 \\
\hline T9 G4B3 & 129.17 & 16.16 & 94.16 \\
\hline T10 G5B1 & 114.75 & 12.85 & 87.90 \\
\hline T11 G5B2 & 119.27 & 13.63 & 89.33 \\
\hline T12 G5B3 & 121.66 & 14.70 & 92.66 \\
\hline T13 G6B1 & 118.95 & 11.49 & 86.66 \\
\hline T14 G6B2 & 122.93 & 14.66 & 93.80 \\
\hline T15 G6B3 & 128.67 & 15.68 & 96.36 \\
\hline S.Em \pm & 1.09 & 0.34 & 0.90 \\
\hline C.D.5\% level & 2.25 & 1.01 & 2.63 \\
\hline
\end{tabular}


Table.2 Mean performance of phenological parameters

\begin{tabular}{|c|c|c|c|}
\hline Treatments & $\begin{array}{l}\text { Days to } \\
\text { first } \\
\text { flower }\end{array}$ & $\begin{array}{c}\text { Days to } \\
50 \% \\
\text { flowering }\end{array}$ & $\begin{array}{l}\text { No. of } \\
\text { flowers/ } \\
\text { cluster }\end{array}$ \\
\hline \multicolumn{4}{|l|}{ Different Genotypes } \\
\hline G1 2018/TOC VAR-1 & 31.76 & 40.51 & 5.27 \\
\hline G2 2018/TOC VAR-2 & 32.35 & 41.73 & 5.40 \\
\hline G4 2018/TOC VAR-4 & 29.85 & 38.36 & 5.85 \\
\hline G5 $2018 / T O C$ VAR-5 & 31.47 & 40.61 & 5.76 \\
\hline G6 $2018 /$ TOC VAR-6 & 30.47 & 40.09 & 5.87 \\
\hline S.Em \pm & 0.22 & 0.34 & 0.034 \\
\hline C.D.5\% level & 0.65 & 0.99 & 0.099 \\
\hline \multicolumn{4}{|l|}{ Vermicompost doses } \\
\hline B1 Control & 32.50 & 41.76 & 5.32 \\
\hline B2 Vermicompost 2.5tha ${ }^{-1}$ & 30.67 & 39.94 & 5.66 \\
\hline B3 Vermicompost 5tha ${ }^{-1}$ & 29.35 & 38.09 & 5.90 \\
\hline S.Em \pm & 0.16 & 0.24 & 0.024 \\
\hline C.D.5\% level & 0.46 & 0.70 & 0.070 \\
\hline \multicolumn{4}{|l|}{ Interaction } \\
\hline T1 G1B1 & 33.01 & 41.93 & 4.89 \\
\hline T2 G1B2 & 31.75 & 40.41 & 5.25 \\
\hline T3 G1B3 & 30.52 & 39.20 & 5.68 \\
\hline T4 G2B1 & 34.79 & 43.88 & 5.14 \\
\hline T5 G2B2 & 32.42 & 41.35 & 5.44 \\
\hline T6 G2B3 & 29.84 & 39.97 & 5.63 \\
\hline T7 G4B1 & 31.46 & 40.40 & 5.69 \\
\hline T8 G4B2 & 29.38 & 38.21 & 5.82 \\
\hline T9 G4B3 & 28.69 & 36.48 & 6.15 \\
\hline T10 G5B1 & 31.5 & 42.09 & 5.37 \\
\hline T11 G5B2 & 30.62 & 40.62 & 5.83 \\
\hline T12 G5B3 & 32.28 & 39.13 & 6.04 \\
\hline T13 G6B1 & 31.77 & 40.50 & 5.54 \\
\hline T14 G6B2 & 29.21 & 39.16 & 5.98 \\
\hline T15 G6B3 & 30.41 & 40.62 & 6.06 \\
\hline S.Em \pm & 0.39 & 0.59 & 0.05 \\
\hline C.D.5\% level & 1.14 & 1.73 & 0.17 \\
\hline
\end{tabular}


Table.3 Mean performance of yield attributing characters

\begin{tabular}{|c|c|c|c|c|c|c|}
\hline Treatments & $\begin{array}{l}\text { Days to } \\
\text { First } \\
\text { Fruit } \\
\text { Picking }\end{array}$ & $\begin{array}{l}\text { Days to last } \\
\text { Fruit } \\
\text { Picking }\end{array}$ & $\begin{array}{l}\text { Fruiting } \\
\text { Span }\end{array}$ & $\begin{array}{l}\text { Fruit } \\
\text { Diameter } \\
\text { (cm) }\end{array}$ & $\begin{array}{l}\text { Average } \\
\text { Fruit } \\
\text { Weight (g) } \\
\text { (5 fruits) }\end{array}$ & $\begin{array}{l}\text { No. of } \\
\text { fruits } \\
\text { /plant }\end{array}$ \\
\hline \multicolumn{7}{|l|}{ Different Genotypes } \\
\hline G1 2018/TOC VAR-1 & 82.5 & 118.0 & 35.4 & 2.43 & 30.53 & 107.56 \\
\hline G2 2018/TOC VAR-2 & 83.0 & 118.8 & 35.8 & 2.54 & 32.14 & 115.92 \\
\hline G4 2018/TOC VAR-4 & 81.2 & 119.4 & 38.2 & 2.67 & 36.15 & 144.33 \\
\hline G5 $2018 /$ TOC VAR-5 & 83.2 & 118.4 & 35.2 & 2.60 & 30.61 & 116.83 \\
\hline G6 2018/TOC VAR-6 & 83.2 & 120.6 & 37.3 & 2.79 & 35.14 & 121.82 \\
\hline S.Em \pm & 0.17 & 0.52 & 0.58 & 0.023 & 0.28 & 1.57 \\
\hline C.D.5\% level & 0.50 & 1.51 & 1.68 & 0.064 & 0.81 & 4.55 \\
\hline \multicolumn{7}{|l|}{ Vermicompost doses } \\
\hline B1 Control & 83.8 & 115.0 & 31.3 & 2.31 & 30.29 & 101.97 \\
\hline B2 Vermicompost 2.5 tha $^{-1}$ & 82.7 & 120.6 & 37.9 & 2.64 & 33.09 & 121.00 \\
\hline B3 Vermicompost 5tha ${ }^{-1}$ & 81.3 & 121.6 & 40.2 & 2.86 & 35.35 & 140.89 \\
\hline S.Em \pm & 0.12 & 0.37 & 0.33 & 0.018 & 0.19 & 1.11 \\
\hline C.D.5\% level & 0.35 & 1.07 & 0.97 & 0.051 & 0.57 & 3.22 \\
\hline \multicolumn{7}{|l|}{ Interaction } \\
\hline T1 G1B1 & 84.0 & 114.3 & 30.3 & 2.23 & 27.10 & 94.61 \\
\hline T2 G1B2 & 82.3 & 121.0 & 38.6 & 2.47 & 30.91 & 105.82 \\
\hline T3 G1B3 & 81.3 & 118.6 & 37.3 & 2.60 & 33.60 & 122.24 \\
\hline T4 G2B1 & 85.0 & 114.3 & 29.3 & 2.26 & 30.38 & 97.363 \\
\hline T5 G2B2 & 83.0 & 122.3 & 39.3 & 2.58 & 31.90 & 117.07 \\
\hline T6 G2B3 & 81.0 & 120.0 & 39.0 & 2.81 & 34.14 & 133.31 \\
\hline T7 G4B1 & 82.0 & 115.3 & 33.3 & 2.32 & 33.91 & 126.18 \\
\hline T8 G4B2 & 81.3 & 119.0 & 37.6 & 2.63 & 35.60 & 138.15 \\
\hline T9 G4B3 & 80.3 & 124.0 & 43.6 & 3.07 & 38.95 & 168.65 \\
\hline T10 G5B1 & 84.3 & 114.3 & 30.0 & 2.39 & 28.52 & 90.717 \\
\hline T11 G5B2 & 83.6 & 119.3 & 35.6 & 2.64 & 30.36 & 117.89 \\
\hline T12 G5B3 & 81.6 & 121.6 & 40.0 & 2.80 & 32.92 & 141.89 \\
\hline T13 G6B1 & 84.0 & 116.6 & 32.6 & 2.47 & 31.58 & 101.01 \\
\hline T14 G6B2 & 83.3 & 121.6 & 38.3 & 2.89 & 36.69 & 126.07 \\
\hline T15 G6B3 & 82.3 & 123.3 & 41.0 & 3.05 & 37.15 & 138.37 \\
\hline S.Em \pm & 0.30 & 0.90 & 0.82 & 0.038 & 0.48 & 2.72 \\
\hline C.D.5\% level & 0.87 & 2.62 & 2.38 & 0.12 & 1.41 & 7.88 \\
\hline
\end{tabular}


Graph.1 Graphical representation of plant height (Morphological character) of Cherry Tomato

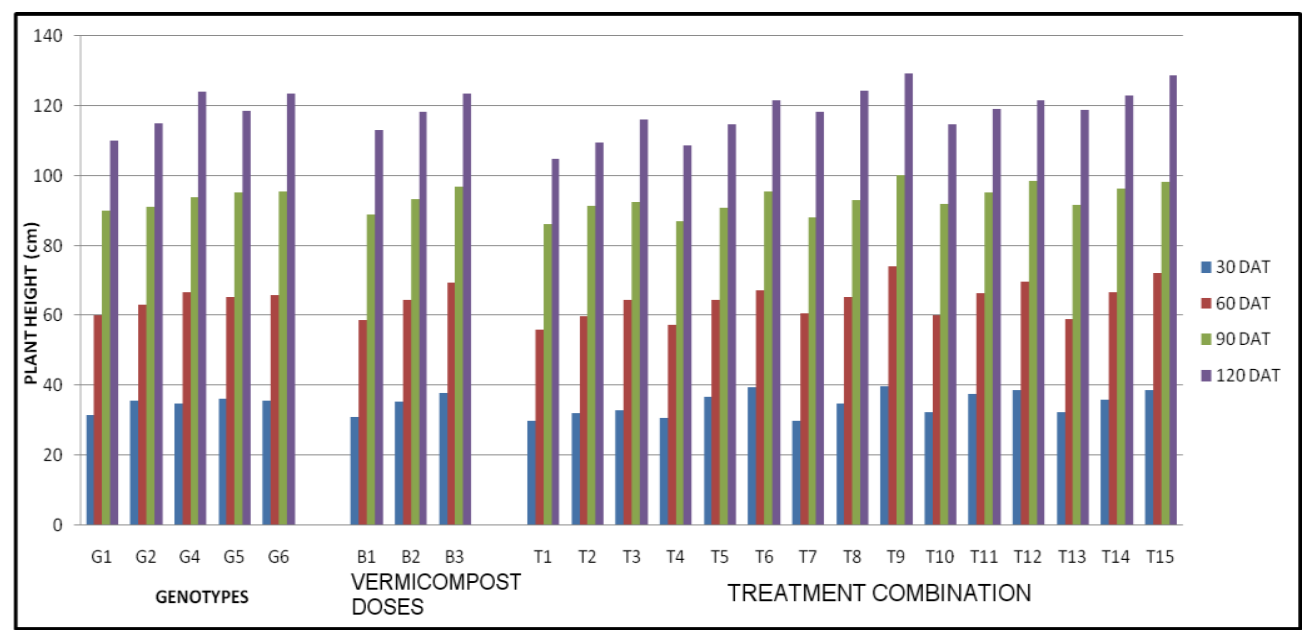

The present research reveals that the vermicompost doses showed a significant effect on Phenological parameters. The minimum days to first flower (29.35 days) and 50 per cent flowering (38.09 days) under vermicompost dose $\left(5\right.$ tha $\left.^{-1}\right)$ along with Azotobacter $\left(4 \mathrm{kgha}^{-1}\right)$ produced highest number of flowers per cluster (5.90) and thus registered as significant more, over the others. The translocation of the photosynthetic assimilates towards the reproductive organs lead to more number of flowers.

Maximum 32.50 days taken to first flowering and 41.76 days to 50 per cent flowering was noted in B1 Control (100\% RDF). This even produced minimum number (5.32) of flowers per cluster. Shukla et al., (2006) reported early flowering due to vermicompost and NPK. Prodhan et al., (2014) and Nizam et al., (2014) both concluded earlier flowering, increase in the number and biomass of the flowers of tomato with vermicompost @5 tha ${ }^{-1}$ and vermicompost @ 10 tha $^{-1}$ than other manure based treatments in their research findings.

Days of first flowering, 50 per cent flowering and number of flowers per cluster were significantly influenced by the various treatment combinations. The interaction
G4B3 (2018/TOC VAR-6 comprising of 5tha 1 Vermicompost + Azotobacter $4 \mathrm{kgha}^{-1}$ ) recorded minimum days (28.69) for days taken to first flowering, for 50 percent flowering (36.48 days) thus producing highest (6.15) number of flowers per cluster. An increase in the number of flowers per cluster was due to the dose of vermicompost which undergoes mineralization and supply macro and micro nutrient for flower development and vigorous plant growth. Soil application rendered easy accessibility of nutrients to plants during flowering. T4 (2018/TOC VAR2 Control) recorded maximum days taken to flowering (34.79) and for 50 percent flowering (43.88 days). Lowest number of flowers (4.89) was obtained in T1.

\section{Yield and yield attributes}

The variations obtained in the yield attributes under different treatments, is in accordance with the morphological and phenological parameters of cherry tomato. Significantly maximum number of fruits per plant was recorded by the genotype G4 2018/TOC VAR-4 (144.3) which were superior to all other genotypes. Prema et al., (2011) and Ramya et al., (2016) also reported more number of fruit cluster plant ${ }^{-1}$ during the evaluation of cherry tomato genotypes. More 
number of fruits per cluster may also be probably due to the genetic potentiality of the genotypes. Least number of 107.56 fruits per plant was noticed in G1 2018/TOC VAR-1. Parvej et al., (2010) also concluded similar findings in the research conducted. An increased fruit set was observed due to high pollen viability and anther dehiscence. Among factor II, Higher number of fruits per plants (140.89) was noted under (B3) 5 tha $^{-1}$ Vermicompost + Azotobacter $4 \mathrm{kgha}^{-1}$ which was at par with B2 and B1. Maximum fruits per plant were obtained by application of vermicompost + FYM was noted by Renuka and Ravishankar (2001). Interaction effect was found to be significant and maximum number of 168.65 fruits per plant was obtained in the treatment combination $\mathrm{T} 9$ 2018/TOC VAR-4 grown with Vermicompost 5tha ${ }^{-1}$ and Azotobacter $4 \mathrm{kgha}^{-1}$ and minimum number of fruits per plant (94.61) was observed in the treatment combination $\mathrm{T} 1$ 2018/TOC VAR-1 under Control (RDF).

Minimum days (81.3 days) to first fruiting was observed in G4 2018/TOC VAR-4 and it was significantly superior over the other treatments while a delay in fruiting (83.0 days) was recorded in G2 2018/TOC VAR-2. Colour development in cherry tomato is affected by the temperature and climate conditions as the higher temperature is required for the development of red colour. As per the consumer preference, picking is done at different intervals as green coloured fruits are not accepted by customers. Early fruiting genotypes are preferred on a commercial scale so that it is purchasable at a specified price. Among the vermicompost doses, the harvesting was earlier (81.3 days) in B3 under vermicompost 5 tha $^{-1}$ and Azotobacter. Delayed first picking (83.8 days) was noted in B1 Control (RDF). The combined effect of Genotype and Vermicompost levels showed significant variation for this character. The minimum
80.3 days taken to first fruit picking were observed in treatment combination T9 2018/TOC VAR-4 grown with Vermicompost $\left(5 \mathrm{tha}^{-1}\right)$ and Azotobacter $4 \mathrm{kgha}^{-1}$ while the Maximum (85 days) was recorded in T4 2018/TOC VAR-2 under Control (RDF). Kumar and Sharma (2007) reported the effects of biofertilizers (Azotobacter, Azospirillum and Pseudomonas) on early picking of cherry tomato fruits.

Statistical analysis of the data revealed significant variation in days to final harvesting of the different Genotypes. The mean performance of the yield attributing characters is tabulated in Table 3. Maximum 120.6 days to last picking were taken by G6 2018/TOC VAR-6 and it was closely preceded by G4 2018/TOC VAR-4 which took 119.4 days. The Minimum days (115 days) were recorded in B1. Among Factor B, Longest span of final harvesting (121.53 days) was found in B3 comprising of Vermicompost 5 tha $^{-1}$ and Azotobacter $4 \mathrm{kgha}^{-1}$ whereas final harvesting was earlier (115 days) in B1 Control (RDF). Among the interaction days to final harvesting was found to be significantly maximum (124 days) in treatment combination T9 2018/TOC VAR-4 with Vermicompost ( 5 tha $^{-1}$ ) and Azotobacter while the minimum 114.3 days were recorded in treatment combinations $\mathrm{T} 1, \mathrm{~T} 4$ and $\mathrm{T} 20$.

The results revealed that all the factors and their interactions differed significantly for the fruiting span of the genotypes of Cherry Tomato. Among Factor A, G4 2018/TOC VAR-4 had maximum fruiting span of 38.2 days and was found to be at par with G6 2018/TOC VAR-6 having fruiting span of 37.3 days. The minimum 35.22 days was recorded in G5 2018/TOC VAR-5. Among Factor B, B3 constituting Vermicompost 5tha ${ }^{1}$ and Azotobacter $4 \mathrm{kgha}^{-1}$ gave the maximum fruiting span of 40.2 days which was found to be significantly superior over the rest while 
minimum was observed in B1 Control (RDF) with 31.1 days. Among treatment combinations, T9 2018/TOC VAR-4 grown with vermicompost 5 tha $^{-1}$ and Azotobacter $4 \mathrm{kgha}^{-1}$ exhibited significant superiority by having a fruiting span of 43.7 days, over the rest of the interactions. Lowest value (29.3 days) for this trait was recorded T4 2018/TOC VAR-2 Control (RDF)

It was observed that mean fruit weight was significantly influenced by Genotype, levels of Vermicompost and their interaction. The mean fruit weight ranged from 30.53 to 36.15 . Significantly superior fruit weight was recorded in G4 2018/TOC VAR-4 (36.15g). G1 2018/TOC VAR-1 (30.53 g) had recorded minimum average fruit weight. This was in conformity with the findings of Prema et al., (2011) and Islam et al., (2012). Maximum average fruit weight of $35.35 \mathrm{~g}$ was recorded under 5 tha ${ }^{-1}$ Vermicompost and Azotobacter $4 \mathrm{kgha}^{-1}$ which was followed by treatment with vermicompost 2.5 tha $^{-1}$ Azotobacter $4 \mathrm{kgha}^{-1}(33.09 \mathrm{~g})$. The least value was recorded under control (30.29 g). Suthar (2009) in his findings acknowledged that the supply of nutrients from inorganic and organic sources such as vermicompost enhanced the partitioning of the photoassimilated from leaf to the fruits ie; from source to sink, which lead to an increase in fruit weight.

The result indicated that among the different treatments, T9 comprising of genotype 2018/TOC VAR-4 under Vermicompost 5tha ${ }^{-1}$ and Azotobacter $4 \mathrm{kgha}^{-1}$ registered maximum fruit weight $(38.95 \mathrm{~g})$ whereas $\mathrm{T} 1$ which is 2018/TOC VAR-1 under control recorded a minimum of $27.10 \mathrm{~g}$ weight. The results are in conformation with the findings of Shukla et al., (2006) and Prativa and Bhattarai (2011) on the effect of fertilizers on yield of Tomato.
A significant difference was observed in cherry tomato genotypes with respect to fruit yield per plant. The mean fruit yield per plant ranged $0.74 \mathrm{~kg}$ to $0.82 \mathrm{~kg}$. The highest mean fruit yield $0.82 \mathrm{~kg}$ per plant was recorded in 2018/TOC VAR-4 which was followed by G6 2018/TOC VAR-6 having $0.81 \mathrm{~kg}$ yield which were statistically at par with each other. G1 2018/TOC VAR-1 possessed the lowest fruit yield $0.74 \mathrm{~kg}$ per plant. The highest fruit yield in G4 is mainly due to maximum number of flowers per clusters and higher fruit weight. This increased yield per plant is due to earliness in flowering, increased number of flower clusters per plant, higher fruit weight and taller plants which intern increases the photosynthetic activity, thus enhancing the yield of the crop. These results commensurate with those obtained by Prema et al., (2011) and Singh et al., (2013).

With regards to Vermicompost doses, the maximum yield of $0.87 \mathrm{~kg}$ per plant was observed in B3 under Vermicompost 5 tha $^{-1}$ and Azotobacter $4 \mathrm{kgha}^{-1}$. However, minimum yield of $0.70 \mathrm{~kg}$ per plant was observed in B1 having $100 \%$ RDF alone. The maximum yield $0.92 \mathrm{Kg}$ per plant was obtained with the treatment combination T9 having 2018/TOC VAR-4 grown with Vermicompost 5 tha $^{-1}$ and Azotobacter $4 \mathrm{kgha}^{-1}$ and possessed significant more over other treatments. Minimum yield $0.67 \mathrm{Kg} \mathrm{pl}^{-1}$ was registered under $\mathrm{T} 1$.

The differences among the genotypes of cherry tomato with respect to yield per hectare were found to be highly significant. Highest fruit yield $272.52 \mathrm{qha}^{-1}$ was recorded in the genotype 2018/TOC VAR-4 which was statistically at par. The genotype 2018/TOC VAR-1 recorded significantly lowest fruit yield $246.52 \mathrm{qha}^{-1}$ which is attributed mainly due to the less number of fruiting clusters per plant and poor fruit set. Similar reports have been reported by Prema et al., (2011), Aguirre and Cabrera (2012) and Razzak et al., (2013) 
in cherry tomato. The data pertaining to the fruit yield per hectare due to Vermicompost levels depicted that the highest yield (289.60 $\mathrm{qha}^{-1}$ ) was obtained by application of B3 (Vermicompost 5tha ${ }^{-1}$ and Azotobacter) and minimum $235.02 \mathrm{qha}^{-1}$ was observed under B1 (100\% RDF alone). Thakur and Rajneesh (2012) have reported the use of organic amendments of vermicompost and noted a high yield of fruit $\left(21.93 \mathrm{~kg} \mathrm{plot}^{-1}, 2.7 \times 2.1 \mathrm{~m}^{2}\right.$ plot size) followed by Azotobacter $\left(5 \mathrm{Kgha}^{-1}\right)$ applied to tomato crop. The combined effect was significant on yield of fruit per plant. The highest yield $307.78 \mathrm{qha}^{-1}$ was obtained from treatment combination T9 2018/TOC VAR-4 Vermicompost 5tha ${ }^{-1}$ and Azotobacter and minimum fruit yield 225.56 $\mathrm{qha}^{-1}$ was registered in T1 2018/TOC VAR-1 under (100\%RDF).

Fruit diameter was found to be the highest $(2.79 \mathrm{~cm})$ in the genotype G6 2018/TOC VAR-6 followed by G4 2018/TOC VAR-4 $(2.64 \mathrm{~cm})$. The least value of fruit width was recorded by $2018 /$ TOC VAR-1 $(2.43 \mathrm{~cm})$. The Characteristic features of Cerasiforme species include shorter fruit length, fruit girth, and fruit width of cherry tomato. The present result correlates with the outcome of Kumar et al., (2014) in cherry tomato. Vermicompost levels showed significant influence on fruit diameter. The lowest value $(2.31 \mathrm{~cm})$ was observed in B1 Control (RDF) while the highest value $(2.86 \mathrm{~cm})$ of the diameter was noted in B3 consisting of Vermicompost 5tha ${ }^{1}$ and Azotobacter. The variations in the yield attributes of tomato is due to different nutrient sources have also been reported by Chatterjee et al., (2014) and Prativa et al., (2011).

As regards, the interaction effect showed that the mean fruit diameter values ranged between $2.23 \mathrm{~cm}$ and $3.07 \mathrm{~cm}$. The treatment combination T9 having 2018/TOC VAR-4 under vermicompost 5 tha $^{-1}$ and Azotobacter produced significantly highest fruit diameter, whereas lowest fruit diameter $(2.23 \mathrm{~cm})$ was recorded in 2018/TOC VAR-1 with control (RDF). This significant variation the yield attributes is due to the different organic sources of nutrients applied. These results are in line with the findings of Prema et al., (2011) in cherry tomato.

The study revealed significant relations among the morphological and phenological characters and yield parameters of cherry tomato genotypes. It can be summarised from the cited literature that the combined application of biofertilizer with organic manure leads to increased vegetative growth and improved productivity of cherry tomato genotypes cultivated under open field conditions. From the above, it can be concluded that G4 2018/TOC VAR-4 grown with vermicompost 5tha-1 and Azotobacter 4kgha-1 was statistically at par over the rest of the treatments and is the best treatment which gave better growth, yield and quality of cherry tomato. Thus, vermicompost and Azotobacter can be used in suitable concentrations to improve yield and morphophenological traits.

\section{Acknowledgement}

The author would like to express heartfelt gratitude to the research guide, Head and staff of the Department of Horticulture, Jawaharlal Nehru Krishi Vishwa Vidyalaya, Jabalpur, Madhya Pradesh for the assistance rendered by them, their suggestions, untiring help and moral support throughout the course of the experiment.

\section{References}

Abduli MA, Amiri L, Madadian E, Gitipour S and Sedighian S. 2013. Efficiency of Vermicompost on Quantitative and Qualitative Growth of Tomato Plants. Int J Environ Research. 7(2):467-472p.

Aguirre, N. C and Cabrera, F. A. V. 2012. 
Evaluating the fruit production and quality of cherry tomato (Solanum lycopersicum var. cerasiforme). Revista Facultad National de Agronomia Medellin. 65(2): 6593-6604.

Alam P.M.M, M.M. Rahman, S. Ahmad, M.A.K. Miah and M.H. Rahman. 2014. Performance of some tomato (Solanum lycopersicum L.) genotypes in summer and winter seasons. The Agriculturists, 12 (2): 64-73.

Anand, M. 2007. Studies on development of F1 hybrids for high yield and quality in tomato. (Lycopersicon esculentum Mill.). Ph.D. Thesis, Tamil Nadu Agricultural University, Coimbatore.

Andrew Smith F. 1994. The tomato in America: Early history, culture and cookery.

Anonymous. 2009. Cherry tomato nutritional information; USDA National Nutritional Database for Standard Reference.

Chatterjee R and Bandyopadhyay S. 2014. Studies on Effect of Organic, Inorganic and Biofertilizers on Plant Nutrient Status and Availability of Major Nutrients in Tomato. International Journal of Bioresource and Stress Management, 5(1): 093-097

Chumyani, Kanaujia, S. P., Singh, A. K. and Singh, V. B., 2012, Effect of integrated nutrient management on growth, yield and quality of tomato (Lycopersicon esculentum Mill.). J. Soil Crops, 22: 5-9.

Gajbhiya, R.P., Sharmar, R.R. and Tewari, R.N. 2003. Effect of biofertilizers on growth and yield parameters of tomato. Indian Journal of Horticulture, 60(4): 368-371.

Islam, M. S, Mohanta, H. C, Ismail, M. R, Rafii, M. Y and Malek, M. A. 2012. Genetic variability and trait relationship in cherry tomato (Solanum lycopersicum L. var. cerasiforme (Dunnal) A. Gray). Bangladesh Journal of Botany. 41(2): 163-167.

Jenkins, J.A. 1948. The origin of cultivated tomato. Econ. Bot., 2: 379-392.

Kumar A, Kumar J, Singh BM., Rajbeer JP and Nathi Ram.2011. Response of biofertilizers and inorganic fertilizers on growth and yield of tomato cv. PUSA RUBY. Asian Journal of Horticulture. 6(2):279-282.

Kumar, K., J. Trivedi, D. Sharma and S.K. Nair. 2014. Evaluation for fruit production and quality of cherry tomato (Solanum lycopersicum L. var. cerasiforme). Trends in Biosciences, 7 (24): 4304-4307.

Lenucci M S, Cadinu D, Taurino M, Piro G and Dalessandro G. 2006. Antioxidant composition in cherry a high pigment tomato cultivars. Journal of Agriculture Food Chemistry 54: 2606-2613

Najar A. and Khan A. B. 2013. Effect of vermicompost on growth and productivity of tomato (Lycopersicon esculentum) under field conditions. ActaBiologicaMalaysiana, 2(1),: 12-21.

Nitzsche, P., W. Tietjen, W. Kline and S. Garrison. 2003. Evaluation of grape and cherry tomatoes in Northern New Jersey. In: Tomato varieties / trial reports - 2003

Nizam R., Ali M. A., Alam K., Mollah M. D. A. and Chowdhury M. S. N. 2014. Yield and profitability of tomato (Lycopersicon esculentum Mill.) as influenced by organic manure and plant spacing. Applied Science Reports, 3(3),:121- 128.

Patil DN, Bhalekar MN, Dhumal SS, Shinde US and Kshirsagar DB. 2010. Effect of organic manures and bio fertilizers on growth and yield of tomato. Journal of Maharashtra Agricultural Universities, 35(3): 396-399.

Parvej, M. R, Khan, M. A. H and Awal, M. A. 2010. Phenological development and production potentials of tomato under polyhouse climate. Journal of Agricultural Sciences. 5(1): 19-31.

Peires, R. 2002. Genetic improvement of tomato variety, Manik.J. Agric. Sci., 4: 199-205.

Prativa KC and Bhattarai BP. 2011. Effect of Integrated Nutrient Management on the Growth, Yield and Soil Nutrient Status in Tomato. Nepal Journal of Science and Technology. 12:23 - 28

Prema, G., Indiresh, K.M. and Santhosha, H.M. 2011. Evaluation of cherry tomato 
(Solanum lycopersicum var.Cerasiforme) genotypes for growth, yield and quality traits. Asian J. Hort., 6 (1):181-184.

Prodhan M. A. A., Ali M. A., Zomo S. A., Sarkar M. D., Parvin K. and Haque F. A. 2014. Organic manure and spacing affecting floral and yield characters of tomato. International Journal of Business, Social and Scientific Research, 2(2),: 9094.

Potaczek H and Michalak H. 1994. Pigmenty ro linne i ich $w^{3} y w$ na barwê owoców pomidora. Mat. z Symp. 30-lecia Inst. Warz., Skierniewice, ss. 41-44

Ramya, R., M. Ananthan and V. Krishnamoorthy. 2016. Evaluation of cherry tomato [Solanum lycopersicum L. var. cerasiforme (Dunnal) A. Gray] genotypes for yield and quality traits. Asian J. Hort., 11 (2): 329-334

Razzak HA, Ibrahim A, Wahb-Allah M, Alsadon A. 2013. Response of cherry Tomato (Solanum lycopersicum var. cerasiforme) to pruning systems and irrigation rates under greenhouse conditions. Asian Journal of Crop Science.; 5(3):275-285.

Renuka, D.M., A.T. Sadashiva, B.T. Kavita, R.C. Vijendrakumar and M.R. Hanumanthiah. 2014. Evaluation of cherry tomato lines (Solanum lycopersicum var. cerasiforme) for growth, yield and quality traits. Plant Archives, 14 (1): 151-154.

Rodge, B. M. and Yadlod, S. S. 2009. Effect of organic and inorganic fertilizers on growth, yield and quality of tomato (Lycopersicon esculentum Mill.). Asian J. Hort. 4(1):221-224.

Senapati H. K., Jena B. and Dash.A. K. 2007. Effect of vermicompost on ragi- tomato cropping systems. Journal of Environment and Ecology, 225(3),: 648-650.

Shukla YR, Thakur AK and Joshi A. 2006. Effect of inorganic and organic fertilizers on yield and horticultural traits in tomato (Lycopersicon esculentum Mill.). 22(2):137-141

Singh, B.K., Pathak, K.A., Boopathi, T. and Deka, B. C. 2010. Vermicompost and NPK Fertilizers Effects on MorphoPhysiological Traits of Plants, Yield and Quality of Tomato Fruits (Solanum lycopersicum L.). Vege. Crop Res. Bulletin. 73:77-86.

Suthar S. 2009b. Impact of vermicompost and composted farmyard manure on growth and yield of garlic (Allium stivum L.) field crop. International Journal of Plant Production 3 (1): 27-38

Taylor, I.B. 1986. Biosystematics of the tomato. In: J.G. Atherton and J. Rudich[eds.], The Tomato Crop: a Scientific Basis for Improvement. Chapman and Hall, London, pp: 1-34.

Thakur KS, Rajeesh Thakur. 2012. Studies on quality parameters and fruit yield of tomato as influenced by organic amendments. Green Frmg.,; 3(6):755-756.

\section{How to cite this article:}

Ankita Sharma, D. P. Sharma, S. K. Pandey and Sharma, T. R. 2020. Differential Responses of Organic Manure and Biofertilizer on Morphophenological Traits and Yield Attributes of Cherry Tomato (Solanum lycopersicum var cerasiformae) Genotypes. Int.J.Curr.Microbiol.App.Sci. 9(10): 3172-3184. doi: https://doi.org/10.20546/ijcmas.2020.910.380 